\title{
Effects of hydrocarbon spills on the temperature and moisture regimes of Cryosols in the Ross Sea region
}

\author{
MEGAN R. BALKS ${ }^{1 *}$, RON F. PAETZOLD², JOHN M. KIMBLE², JACKIE AISLABIE ${ }^{3}$ and IAIN B. CAMPBELL ${ }^{4}$ \\ ${ }^{1}$ Department of Earth Sciences, University of Waikato, Private Bag 3105, Hamilton 2001, New Zealand \\ ${ }^{2}$ Natural Resources Conservation Service, USDA, Federal Building Room 152, 100 Centennial Mall North, Lincoln, NE 68508, USA \\ ${ }^{3}$ Landcare Research, Private Bag 3127, Hamilton 2001, New Zealand \\ ${ }^{4}$ Land and Soil Consultancy Services, 23 View Mount, Stoke, Nelson, New Zealand \\ *Corresponding author:m.balks@waikato.ac.nz
}

\begin{abstract}
Hydrocarbon spills have occurred on Antarctic soils where fuel oils are utilized, moved or stored. We investigated the effects of hydrocarbon spills on soil temperature and moisture regimes by comparing the properties of existing oil contaminated sites with those of nearby, uncontaminated, control sites at Scott Base, the old Marble Point camp, and Bull Pass in the Wright Valley. Hydrocarbon levels were elevated in fuel-contaminated samples. Climate stations were installed at all three locations in both contaminated and control sites. In summer at Scott Base and Marble Point the mean weekly maximum near surface $(2 \mathrm{~cm}$ and $5 \mathrm{~cm}$ depth) soil temperatures were warmer $(P<0.05)$, sometimes by more than $10^{\circ} \mathrm{C}$, at the contaminated site than the control sites. At Bull Pass there were no statistically significant differences in near-surface soil temperatures between contaminated and control soils. At the Scott Base and Marble Point sites soil albedo was lower, and hydrophobicity was higher, in the contaminated soils than the controls. The higher temperatures at the Scott Base and Marble Point hydrocarbon contaminated sites are attributed to the decreased surface albedo due to soil surface darkening by hydrocarbons. There were no noteworthy differences in moisture retention between contaminated and control sites.
\end{abstract}

Received 1 June 2001, accepted 12 July 2002

Key words: Antarctica, fuel, human impacts, oil, permafrost, soil

\section{Introduction}

Soils in the Ross Sea region of Antarctica are formed in an environment of low precipitation and a mean annual air temperatures below $-10^{\circ} \mathrm{C}$. Because of the slow rate at which Antarctic soil processes operate, the soils are considered to be particularly susceptible to human induced damage (Campbell et al. 1998a). All human activities in Antarctica depend on fuels for transport and energy, hence petroleum related contaminants are widespread (Cripps \& Priddle 1991), but are limited to isolated occurrences with a total area, in the Ross Sea Region, of only a few hectares. At most Antarctic sites where intensive human activity has been undertaken fuel spills have occurred, and they have been reported at most major bases (e.g. Kerry 1990, Tumeo \& Wolk 1994, Cripps \& Shears 1997, Balks et al. 1998, Aislabie et al. 1998). Localised oil contamination of soil was also a consequence of the Dry Valley Drilling Project (Parker \& Howard 1977). Hydrocarbons can accumulate in Antarctic soils and migrate into the soil subsurface (Balks et al. 1998), and changes in microbial populations have been reported at fuel-contaminated sites (Aislabie et al. 1998). Very little is known about the effects of hydrocarbon contaminants on the physical properties of Antarctic soils.

The gravimetric moisture content of the active layer of soils in the Ross Sea region of Antarctica is typically between 1 and 10\% (Campbell et al. 1994, 1997a). There is some seasonal variability at sites where snow-melt has been shown to result in an increase in soil moisture content to values of up to $15 \%$ for short periods (up to 14 days, Campbell et al. 1997a). Within the underlying permafrost in coastal areas, moisture contents are variable ranging from lenses of ice $(100 \%$ moisture), to less than $10 \%$, with an average of about $40 \%$ (Campbell et al. 1998b). In dry inland areas, such as the Wright Valley, soil moisture contents, in both the permafrost and the active layer, are generally less than $10 \%$. The osmotic effect of salts in soils from an older surface in the Dry Valleys was shown to play a major role in determining the soil water potential (Klingler \& Vishniac 1988). However, very little investigation has been undertaken into the available water capacity of Antarctic soils. The addition of hydrocarbon material to soils could potentially impact on the soil moisture regime. There is potential for hydrocarbons to cause an increase in soil hydrophobicity, and therefore, a decrease in soil moisture holding capacity. Alternatively, an increase in soil carbon content could contribute to increased soil water holding capacity. Measurement of soil moisture retention in hydrocarbon contaminated and control soils will provide some preliminary information on any effects that are occurring.

Summer soil surface temperatures ranging from +18 to $-15^{\circ} \mathrm{C}$ have been reported for short measurement periods for three sites in the Ross Sea region (Campbell et al. 1997b), and for a whole year, giving a range from +15 to $-34^{\circ} \mathrm{C}$, at 


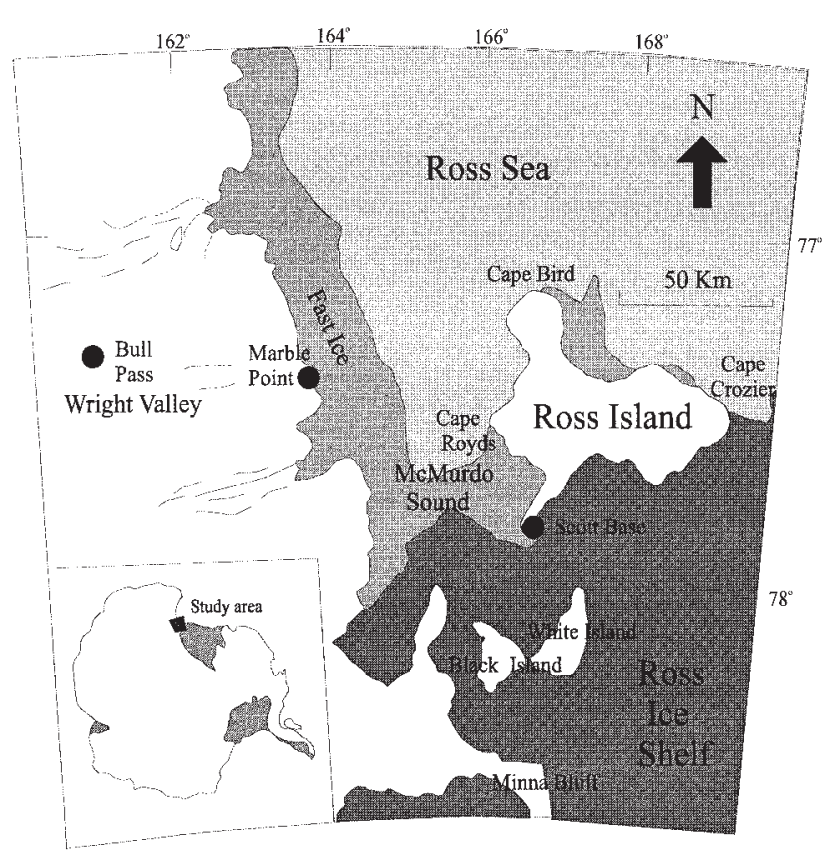

Fig. 1. Location of hydrocarbon contaminated soil sampling sites at Scott Base, Marble Point, and Bull Pass.

Marble Point (Balks et al. 1995). The main factor affecting the diurnal thermal regime of Antarctic soils in summer is surface albedo (Campbell et al. 1997b). It is hypothesized that where fuel spills result in formation of a dark surface coating, thus decreasing the surface albedo, the soil's capacity to absorb heat will be increased.

In this paper we present data on the temperature and moisture regimes of hydrocarbon-contaminated and nearby control soils from three contrasting sites in the Ross Sea region of Antarctica.

\section{Materials and methods}

\section{Site and soil description}

Hydrocarbon contaminated and nearby control sites were identified at Scott Base, Marble Point, and near Bull Pass in Wright Valley (Fig. 1). At Scott Base, a hydrocarboncontaminated site was sampled near a former storage area for drums of hydraulic and lubricating oils (Fig. 2a). Spills at the drum storage site are likely to have occurred intermittently from possibly as long ago as 1960 until the storage area was decommissioned in 1998. At Marble Point, the soil was sampled near the old Marble Point camp that was inhabited from 1957 to about 1963 (Broadbent 1994). Oil stains were visible on the surface of the soil and it is assumed they have been there for over 30 years (Fig. 2b). The contaminated soil in the Wright Valley came from a spill site near Bull Pass that occurred during seismic borehole drilling activities in 1985. The sampled site at Bull Pass was $10 \mathrm{~m}$ downhill from the bore-hole and it is likely the fuel flowed to the sampling site along the interface between the soil and the, relatively impermeable, underlying bedrock. There is no visible surface expression of the spill at Bull Pass. At each of the sites the extent of the contamination appeared to be less than $100 \mathrm{~m}^{2}$.

The soils at the three sampling sites have differing parent materials and climates, leading to a range in soil properties and differences in soil classifications (Table I). The control sites were all within $400 \mathrm{~m}$ of the oil contaminated sites and the contaminated soils were generally similar to those of the adjacent control sites. However, in the contaminated soil at the Marble Point site, the glacic (ice saturated) layer, that was described in the control site and is widespread in the Marble Point area, was not observed. At the Bull Pass contaminated site, the granite bedrock was encountered at a depth of $65 \mathrm{~cm}$, whereas bedrock was at a depth greater than $1 \mathrm{~m}$ at the control site.

\section{Hydrocarbon analyses of soil}

For total petroleum hydrocarbon (TPH) analyses, c. $50 \mathrm{~g}$ of soil was placed in gas-tight metal cans, and stored until analysis in New Zealand. Levels of TPH were determined by extracting the samples in methylene chloride, then
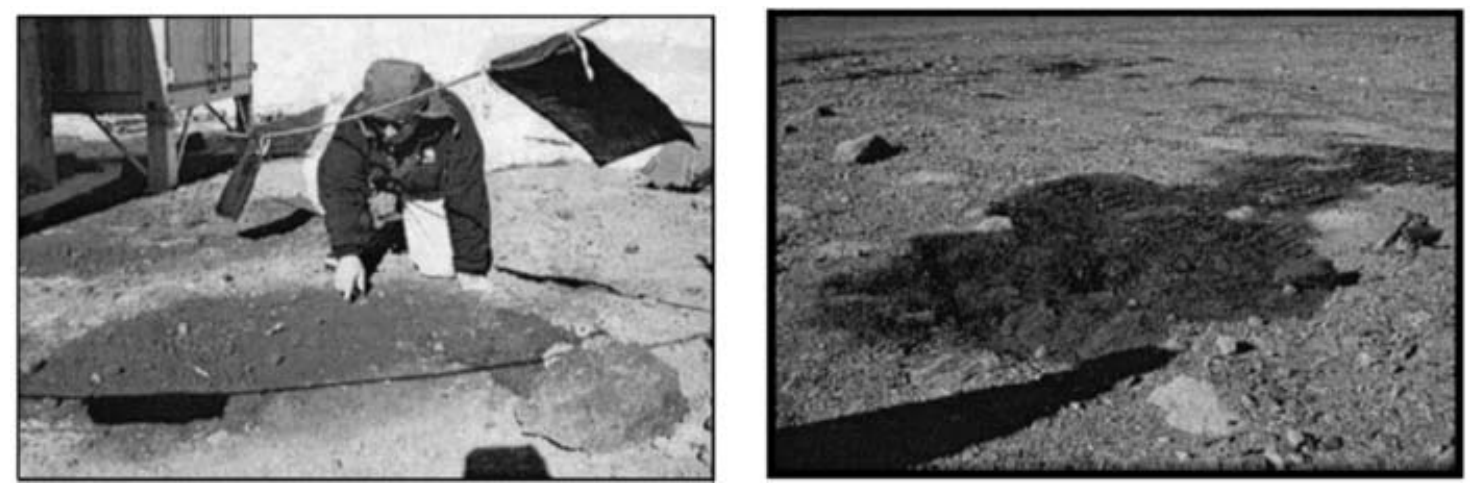

Fig. 2. Soil surfaces darkened by hydrocarbon materials at a. Scott Base former drum storage area and b. Marble Point old campsite. The oil darkened area is $c .3 \mathrm{~m}$ wide at the widest point. 
Table I. Soil and site descriptions for control sites at Scott Base, Marble Point and Bull Pass.

\begin{tabular}{|c|c|c|c|}
\hline & Scott Base & Marble Point & Bull Pass \\
\hline GPS location & $\begin{array}{l}77^{\circ} 50^{\prime} 53.9^{\prime \prime} \mathrm{S} \\
166^{\circ} 45^{\prime} 40.7^{\prime \prime} \mathrm{E}\end{array}$ & $\begin{array}{l}77^{\circ} 25^{\prime} 9.9^{\prime \prime} \mathrm{S} \\
163^{\circ} 40^{\prime} 55.1^{\prime \prime} \mathrm{E}\end{array}$ & $\begin{array}{l}77^{\circ} 31^{\prime} 05.7^{\prime \prime S} \\
161^{\circ} 51^{\prime} 57.3 " \mathrm{E}\end{array}$ \\
\hline *Soil classification & Typic anhyorthel & Calcic anhyorthel & Nitric anhyorthel \\
\hline $\begin{array}{l}\text { Brief soil } \\
\text { description }\end{array}$ & $\begin{array}{l}\text { Stony, gravelly sands derived mainly } \\
\text { from basalt with ice-cemented } \\
\text { permafrost below c. } 30 \mathrm{~cm} \text {. }\end{array}$ & $\begin{array}{l}2 \mathrm{~cm} \text { of desert pavement gravels over sandy } \\
\text { gravel with }>30 \% \text { boulders } / \text { stones. Ice- } \\
\text { dominated horizon from } 87-100+\mathrm{cm} \text {. }\end{array}$ & $\begin{array}{l}2 \mathrm{~cm} \text { of gravel desert pavement over } 1+\mathrm{m} \\
\text { of silt with a few large rocks. Visible salt } \\
\text { accumulation on profile face. No ice-cement. }\end{array}$ \\
\hline
\end{tabular}

*Soil classifications are those of Soil Survey Staff (1998).

analysing the extracts by capillary gas chromatography with a flame ionisation detector, essentially as outlined in Ministry for the Environment (1999). Sampling depths were determined following pedological observation with between two and seven samples taken per site.

\section{Climate data collection, and determination of surface albedo, soil hydrophobicity, and soil moisture retention}

Soil climate stations were established at the three control sites, each in an undisturbed area typical of the surrounding terrain and soils, and in hydrocarbon contaminated sites, at Scott Base, Marble Point, and Bull Pass. A data logger (CR10X, Campbell Scientific Incorporated (CSI), Logan, Utah) was installed at each site with sensors to record air temperature, relative humidity, solar radiation, and wind speed and direction. Thermistor temperature probes (Campbell107, CSI) and Vitel moisture probes (hydra type A, Stevens Vitel Inc, Chantilly, VA) were installed at depths of $2 \mathrm{~cm}$ to $1.2 \mathrm{~m}$. Measurements of atmospheric variables were made at 10 second intervals. Soil variables were measured every 15 minutes. All measurements were averaged and recorded hourly with data downloaded annually.

Comparative surface albedo was measured using a pyranometer (LI200x, Licor, Lincoln, Nebraska) attached to a CR10x datalogger. The pyranometer was alternated between upward and downward positions to detect incoming and reflected radiation. All reported measurements were made in bright sunshine when the sun was high in the sky. Comparisons between contaminated and adjacent control sites were made within 20 minutes of

Table II. Levels of total petroleum hydrocarbons (TPH)*, classes of hydrocarbons, identified at each site using GC", and descriptions of site contamination.

\begin{tabular}{lrll}
\hline Location & TPH $\mu \mathrm{g} \mathrm{g}^{-1}$ dry weight & Class of hydrocarbons & Description of site contamination \\
\hline $\begin{array}{l}\text { Scott Base: drum storage site } \\
25100\end{array}$ & C10-C40 $n$-alkanes & \\
$0-2 \mathrm{~cm}$ & 4190 & polyaromatic hydrocarbons & $\begin{array}{l}\text { Storage area for drums of hydraulic and lubricating oils. } \\
\text { Hydrocarbons spilled during movement and distribution. }\end{array}$ \\
$\begin{array}{l}\text { Marble Point: Old Marble Point Camp site } \\
0-3 \mathrm{~cm}\end{array}$ & 29100 & C13-C40 $n$-alkanes \\
$3-12 \mathrm{~cm}$ & 18300 & polyaromatic hydrocarbons & Oil stains on soil surface at site of Old Marble Point Camp \\
$12-27 \mathrm{~cm}$ & 200 & hopanes & assumed to be hydraulic and lubricating oils. \\
$27-40 \mathrm{~cm}$ & $<20$ & & \\
$40-55 \mathrm{~cm}$ & $<20$ & & \\
$55-75 \mathrm{~cm}$ & $<20$ & C9-C15 $n$-alkanes & \\
Bull Pass: seismic bore-hole site & & Diesel fuel Arctic was spilled in 1985 during seismic bore-hole \\
$0-2 \mathrm{~cm}$ & $<30$ & & drilling. Contaminated surface soil was removed. \\
$2-8 \mathrm{~cm}$ & 260 & & Sample site was downslope from original spill site. \\
$8-16 \mathrm{~cm}$ & 1260 & & \\
$16-35 \mathrm{~cm}$ & 960 & & \\
$35-50 \mathrm{~cm}$ & 2470 & & \\
$50-60 \mathrm{~cm}$ & 9000 & & \\
$60-65 \mathrm{~cm}$ & 9500 & & \\
\hline
\end{tabular}

*Total petroleum hydrocarbon levels in soil from control sites near the spill sites were $<30 \mu \mathrm{g} \mathrm{g}^{-1}$ dried weight, except for Scott Base site which was $<500 \mu \mathrm{g} \mathrm{g}{ }^{-1}$. \#Data from Aislabie et al. (1999), Weston \& Aislabie (unpublished). 

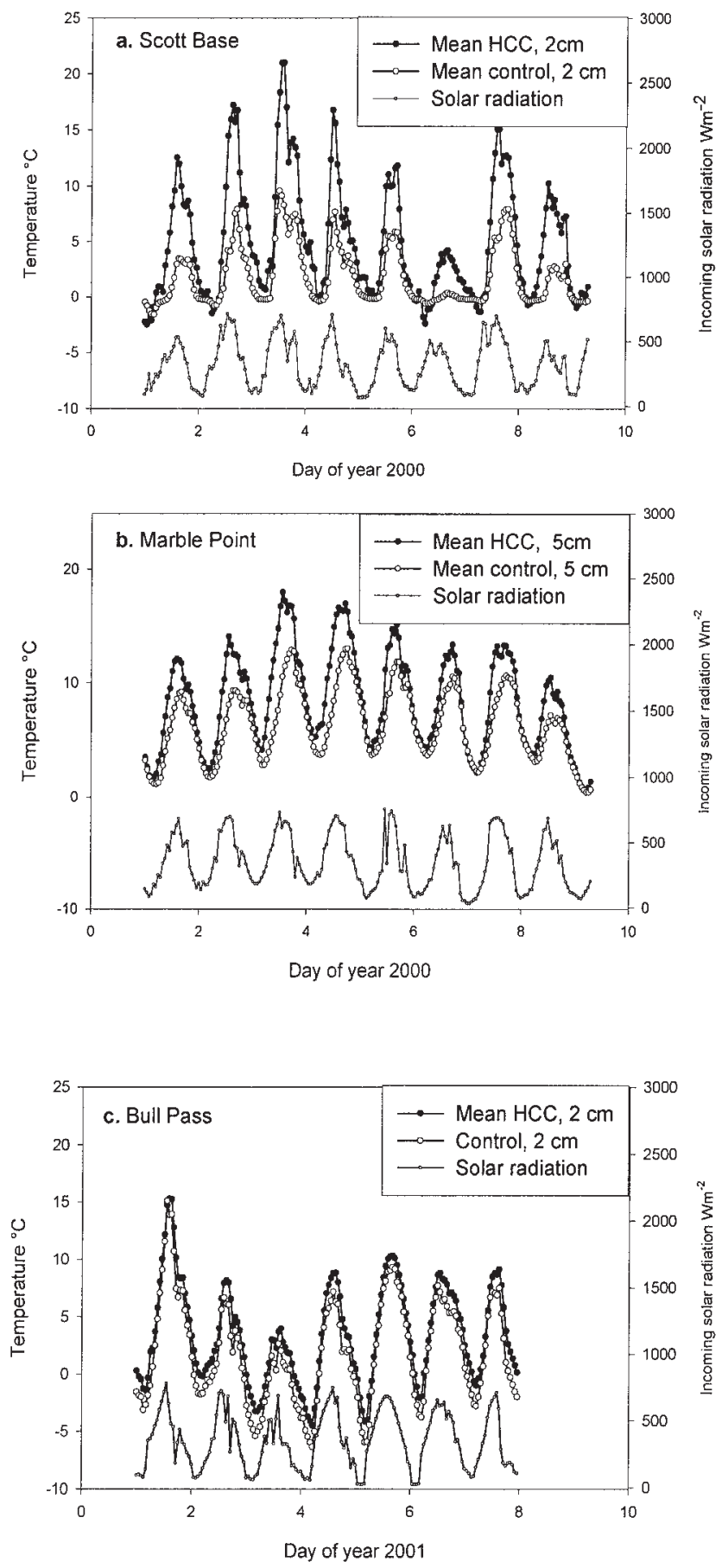

Fig. 3. Examples of soil temperatures and incoming solar radiation, at hydrocarbon contaminated (HCC) and control sites at a. Scott Base, $2 \mathrm{~cm}$ depth, b. Marble Point, $5 \mathrm{~cm}$ depth, and c. Bull Pass, $2 \mathrm{~cm}$ depth.

each other. Each albedo calculation was made from the mean of five incoming and five reflected radiation measurements made over a one minute interval. Less than 10 minutes elapsed between the measurement of incoming and reflected radiation for each albedo calculation. A detailed description of the method is given in Holmes (2002).

Soil moisture retention was determined using a Haines apparatus (2.5 and $5 \mathrm{kPa})$ and pressure plate apparatus (10, $20,40,100,300$ and $1500 \mathrm{kPa}$ ) following the methods of Klute (1986). Field-moist soil samples, sieved through an $8 \mathrm{~mm}$ sieve, were repacked to achieve a bulk density of c. $1.6 \mathrm{~g} \mathrm{~cm}^{-3}$. Soil hydrophobicity was determined using the molarity of ethanol droplet method of Carter \& Hamilton (1995) with five replications of each measurement.

\section{Statistical analyses}

Statistical comparisons in soil temperatures between oiled and control sites were made using paired t-tests on weekly maximum temperatures using Microsoft Excel 2001.

\section{Results and discussion}

Hydrocarbon analysis

The concentrations of the hydrocarbons in the contaminated soils vary due to differences in the mixtures of hydrocarbons spilled, the amount and rate at which they were spilled, soil permeability, and the time since spillage (Table II). At the contaminated sites, hydrocarbon levels ranged from below detectable limits to $29100 \mu \mathrm{g} \mathrm{g}^{-1}$ dried soil. These levels were within the ranges reported for contaminated soils from around the H. Arctowski Polish station (Kryszowska 1990), McMurdo station (Tumeo \& Wolk 1994), Palmer station (Kennicutt et al. 1992) and Davis station (Green \& Nichols 1995).

Fuels spilled on Antarctic soils can move into subsurface soils (Balks et al.1998, Gore et al. 1999). Hydrocarbons were detected in subsurface soils from all the contaminated sites sampled (Table II). The mobility of the spilled fuel depends on the fuel's physical characteristics (Gore et al. 1999). Lighter fuels such as JP8 jet fuel or Diesel Fuel Arctic (DFA) are highly mobile, whereas heavier hydraulic and lubricating oils are less mobile. At the DFAcontaminated Bull Pass site, hydrocarbons were detected at high levels at the $60 \mathrm{~cm}$ depth where the mobile fuel was perched on bedrock. In contrast, at Marble Point hydrocarbon levels were below detectable levels in soil from the $27-40 \mathrm{~cm}$ depth where relatively less mobile oil had not penetrated a clay-rich soil horizon of low permeability. At Scott Base, soil sampling was limited by the presence of ice-cemented ground at about $20 \mathrm{~cm}$ depth in early December. Chemical characterization of the hydrocarbon contaminants from all sites identified $n$ alkanes and aromatic compounds (Table II), some of which occur on the USEPA Priority Pollutant List.

\section{Soil temperature profiles}

During fine summer weather, when the soils are free of 

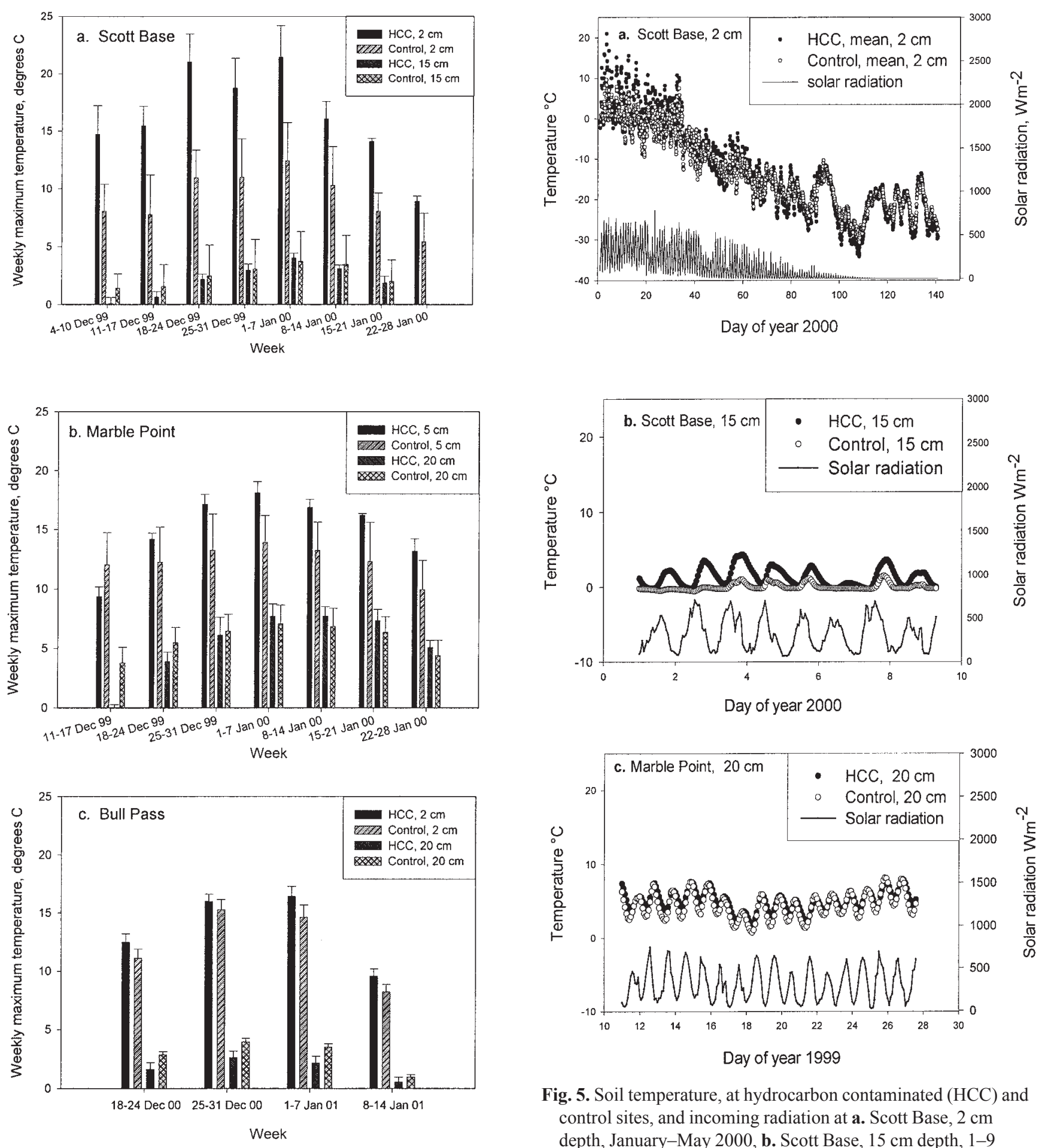

Fig. 4. Mean weekly maximum soil temperatures for hydrocarbon contaminated (HCC) and control sites at a. Scott Base, 2 and $15 \mathrm{~cm}$ depths, b. Marble Point, 5and $20 \mathrm{~cm}$ depths, and c. Bull Pass, 2 and $20 \mathrm{~cm}$ depths. Data are means of between 2 and 7 replicates. Error bars are one standard deviation of the mean.

snow, the soil temperature at the contaminated soil surfaces at Scott Base and Marble Point were warmer $(P<0.05)$,

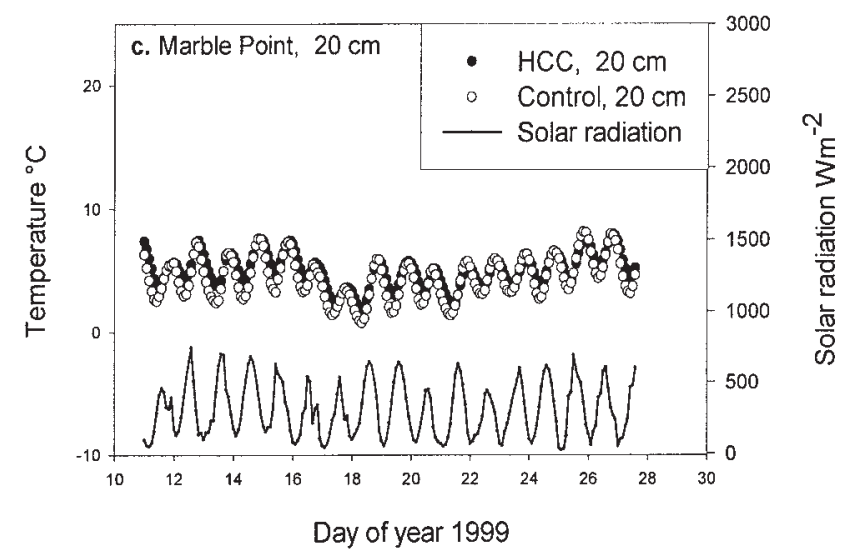

Fig. 5. Soil temperature, at hydrocarbon contaminated (HCC) and control sites, and incoming radiation at a. $\mathrm{Scott}$ Base, $2 \mathrm{~cm}$ depth, January-May 2000, b. Scott Base, 15 cm depth, 1-9 January 2000, c. Marble Point, $20 \mathrm{~cm}$ depth, 11-29 January 2000.

sometimes by up to $12^{\circ} \mathrm{C}$, than the adjacent control sites, during the middle of the day (Figs $3 a \& 3 b, 4 a \& 4 b$ ). There was no significant surface warming at the Bull Pass site (Figs $3 c \& 4 c$ ) where there was no surface evidence of the hydrocarbon contamination. 
Soil temperature fluctuations in summer are strongly correlated with incoming solar radiation (Fig. 3). The surface temperature differences between contaminated and control sites at Scott Base and Marble Point occur while there is appreciable incoming solar radiation (Figs $3 a \& 5 a$ ), and no surface snow cover. For instance, the lack of warming effect at Marble Point in December 1999 (Fig. 4) is attributed to discontinuous snow cover occurring at the contaminated site. However, over the winter period, when soil temperatures are driven by air temperatures, and not by direct radiative heating, the control and contaminated sites have similar temperatures (Fig. 5a).

The effect of increased surface temperature at Scott Base appeared to penetrate to $15 \mathrm{~cm}$ depth (Fig. $5 \mathrm{~b}$ ) however the differences in the maximum temperatures were not significant (Fig. 4a). At the $20 \mathrm{~cm}$ depth, at Marble Point, there was no evidence of differences between the contaminated and control sites (Figs $4 \mathrm{~b} \& 5 \mathrm{c}$ ).

Due to the large dataset only examples of the temperature data could be included here. The full dataset, and details of statistical analyses, are available, on request, from the authors.

\section{Soil surface albedo, hydrophobicity, and moisture retention}

Lower soil surface albedos were measured on soil surfaces darkened by hydrocarbon contaminants, compared to neighbouring controls, at both Scott Base and Marble Point (Table III). However, where there was no visible surface colour change, at the Bull Pass site, there was no significant difference in surface albedo.

The oil contaminated soil surface at Scott Base was
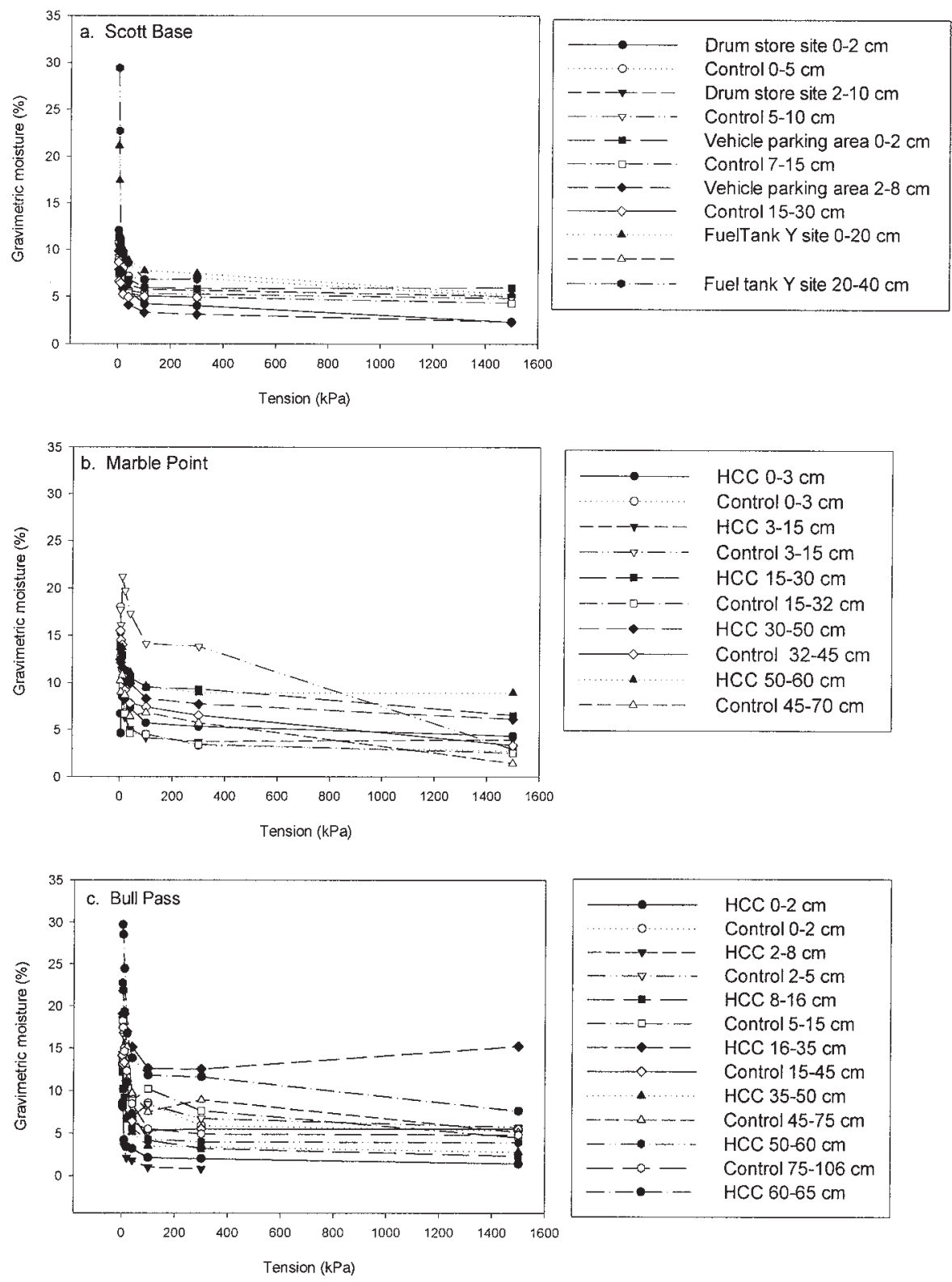

Fig. 6. Soil moisture retention for control and hydrocarbon-contaminated soils at a. Scott Base, b. Marble Point and c. Bull Pass. Data are means of between 2 and 13 replicates. $\mathrm{HCC}=$ hydrocarbon contaminated. 
Table III. Soil surface albedo (after Holmes 2002) and hydrophobicity for hydrocarbon contaminated (HCC) and control sites at Scott Base, Marble Point, and Bull Pass.

\begin{tabular}{|c|c|c|c|}
\hline & \multicolumn{2}{|c|}{ Surface albedo } & \multirow{2}{*}{$\begin{array}{l}\text { Surface soil hydrophobicity } \\
\text { (molarity of ethanol droplet) }\end{array}$} \\
\hline & $\%$ & $n^{\#}$ & \\
\hline \multicolumn{4}{|l|}{ Scott Base: } \\
\hline HCC site & 5 & 2 & $>1$ \\
\hline Control site & 10 & 2 & 0 \\
\hline \multicolumn{4}{|l|}{ Marble Point: } \\
\hline HCC site & 11 & 2 & 0.2 \\
\hline Control site & 25 & 3 & 0 \\
\hline \multicolumn{4}{|l|}{ Bull Pass: } \\
\hline HCC site & 20 & 1 & 0 \\
\hline Control site & 21 & 1 & 0 \\
\hline
\end{tabular}

${ }^{\#} n=$ number of replications, *mean of 5 replications

strongly hydrophobic and at Marble Point it was weakly hydrophobic (Table III). However, there was no evidence of hydrophobicity in the control soils, or in subsurface samples, at any of the contaminated sites sampled. The hydrophobicity of the oil contaminated sites, except for the Scott Base surface soil, was unexpectedly low and not expected to inhibit moisture movement. The strongly hydrophobic surface soil at the Scott Base contaminated site may inhibit moisture movement into the soil.

Moisture retention data (Fig. 6) showed no significant differences between contaminated and control soil samples. The soils, at their field moisture content of $1-5 \%$ in the surface $10 \mathrm{~cm}$, are at or below $-1500 \mathrm{kPa}$ water potential, thus confirming the limited availability of water near the soil surface. Different micro-organisms have different levels of tolerance for low water potentials, and generally fungi are more tolerant of lower water potentials than bacteria (Skujins 1984). While some micro-organisms are growth limited at water potentials below $-1500 \mathrm{kPa}$, some xerophyllic micro-organisms have been reported to operate in soils with water potentials of -1500 to $-8000 \mathrm{kPa}$ and herperxerophyllic microbes may operate at water potentials below $-8000 \mathrm{kPa}$ (Skujins 1984). Moisture availability is likely to be one of the limitations to some forms of microbial activity near the soil surface at the sites in this study. In the Ross Sea region, where there is ice-cemented permafrost, soil moisture contents often reach about $10 \%$ by weight near the permafrost interface, which equates to a moisture retention of less than $200 \mathrm{kPa}$, so would not be expected to be limiting to microbial activity.

\section{ConclusFion}

Hydrocarbon contamination has been shown to occur at the three sites sampled. Where hydrocarbons accumulate at the soil surface they are contributing to increased soil hydrophobicity and decreased surface albedo. The warmer temperatures near the soil surface in the hydrocarbon contaminated sites at Scott Base and Marble Point, during sunny periods when the soils are snow free, are attributed primarily to the decreased surface albedo. As expected, no difference in temperature between contaminated and control sites was found in the surface soils at Bull Pass where there was no change in soil-surface albedo at the contaminated site.

Although the temperature warming on the oil-darkened surfaces is limited to $2-12^{\circ} \mathrm{C}$ for up to six hours per day, over the short summer period when the soils are snow-free, even this increase could provide some advantage for microbial activity. For instance, microbial activity has been shown to be strongly related to temperature with Rivkina et al. (2000) reporting a minimum doubling time of one day at $5^{\circ} \mathrm{C}$, and 20 days at $-10^{\circ} \mathrm{C}$, for bacteria from Siberian permafrost. Friedmann et al. (1987) suggested $15^{\circ} \mathrm{C}$ as an optimum temperature for microbial activity in relation to Antarctic micro-organisms and $-10^{\circ} \mathrm{C}$ as the minimum temperature for biological activity. The surface warming reported here indicates that the hydrocarbon-contaminated soil surfaces at Scott Base are closer to optimum temperatures for biological activity for longer periods than the control soils. However, the moisture retention data, when considered along with previously published Antarctic soil moisture contents (e.g. Campbell et al. 1994, 1997a), suggest that, near the soil surface, moisture may be limiting to many micro-organisms most of the time. There is a need for further investigation of moisture availability to microorganisms in Antarctic soils.

\section{Acknowledgements}

This work was supported by funding from the Foundation for Research, Science and Technology, New Zealand (C09X0018). Antarctica New Zealand provided logistic support. Rachel Standish and David Holmes provided technical assistance. We thank the referees, Drs D. Gore and M. Riddle, for their helpful comments.

\section{References}

Aislabie, J., McLeod, M. \& Fraser, R. 1998. Potential for biodegradation of hydrocarbons in soil from the Ross Dependency, Antarctica. Applied Microbiology and Biotechnology, 49, 210-214.

Aislabie, J., Balks, M.R., Astori, N., Stevenson, G. \& Symons, R. 1999. Polycyclic aromatic hydrocarbons in fuel-oil contaminated soils, Antarctica. Chemosphere, 39, 2201-2207.

Balks, M.R., Campbell, D.I., Campbell, I.B. \& Claridge, G.G.C. 1995. Interim results of 1993/94 soil climate, active layer, and permafrost investigations at Scott Base, Vanda and Beacon Heights, Antarctica. University of Waikato, Antarctic Research Unit Special Report, No. 1, $64 \mathrm{pp}$.

Balks, M.R., Aislabie, J. \& Foght, J.M. 1998. Preliminary assessment of the constraints to biodegradation of fuel spills in Antarctic soils. Symposium 38, Proceedings 16th World Congress of Soil Science, Montpelier, France, 20-26 August 1998. Montpelier: International Union of Soil Science, CD-ROM. 
BRoAdBent, N.D. 1994. An archaeological survey of Marble Point, Antarctica. Antarctic Journal of the United States, 29(4), 3-6.

Campbell, D.I., MacCulloch, R.J.L. \& CAmpBell, I.B. 1997b. Thermal regimes of some soils in the McMurdo Sound region, Antarctica. In Lyons, W.B., Howard-Williams, C. \& Hawes, I., eds. Ecosystem processes in Antarctic ice-free landscapes. Rotterdam: A.A. Balkema, $45-56$.

Campbell, I.B., Claridge, G.G.C., Campbell, D.I. \& Balks, M.R. 1994. The effect of human activities on moisture content of soils and underlying permafrost from the McMurdo Sound region, Antarctica. Antarctic Science, 6, 307-14.

Campbell, I.B., Claridge, G.G.C., Balks, M.R. \& CAmpBell, D.I. 1997 a. Moisture content in soils of the McMurdo Sound and Dry Valley region of Antarctica. In Lyons, W.B., Howard-Williams, C. \& Hawes, I., eds. Ecosystem processes in Antarctic ice-free landscapes. Rotterdam: A.A. Balkema, 61-76.

Campbell, I.B., Claridge, G.G.C., Campbell, D.I. \& Balks, M.R. 1998a. The soil environment of the McMurdo Dry Valleys, Antarctica. Antarctic Research Series, 72, 297-322.

Campbell, I.B., Claridge, G.G.C., Campbell, D.I. \& Balks, M.R. 1998 b. Permafrost properties in the McMurdo Sound-Dry Valleys region of Antarctica. In Lewkowicz A.G. \& Allard, M., eds. Permafrost. Proceedings of the Seventh International Conference, June 23-27, 1998, Yellowknife, Canada. Yellowknife, NWT: International Permafrost Association, 121-126.

CARTER, D.J. \& Hamilton, G.J. 1995. Water repellency - the molarity of ethanol droplet test. In Coughlan, K.J., McKenzie, N.J., McDonald, W.S.A. \& Creswell, H.P., eds. Soil physical measurement and interpretation for land evaluation. Australian Soil and Land Survey Handbook series. Volume 5. Australian Collaborative Land Evaluation Program. Canberra: CSIRO.

CRiPPS, G.C. \& Priddle, J. 1991. Hydrocarbons in the Antarctic environment. Antarctic Science, 3, 233-250.

CRIPPS, G.C. \& SHEARS, J. 1997. The fate in the marine environment of a minor diesel fuel spill from an Antarctic research station. Environmental Monitoring and Assessment, 46, 221-232.

Friedmann, E.I., McKay, C.P. \& NienOw, J.A. 1987. The cryptoendolithic microbial environment in the Ross Desert of Antarctica: satellitetransmitted continuous nanoclimate data 1984-1986. Polar Biology, 7, $273-287$.
Gore, D.B., Revill, A.T. \& Guille, D. 1999. Petroleum hydrocarbons ten years after spillage at a helipad in Bunger Hills, East Antarctica. Antarctic Science, 11, 427-429.

Green, G. \& Nichols, P.D. 1995. Hydrocarbons and sterols in marine sediments and soils at Davis station, Antarctica: a survey for human derived contaminants. Antarctic Science, 7, 137-144.

Holmes, D.J. 2002. The fate and effects of JP-5 fuel in Antarctic soil: a controlled experiment at Scott Base, Antarctica. MSc thesis, University of Waikato, NZ, 94 pp. [Unpublished]

Kennicutt II, M.C., McDonald, T.J., Denoux, G.J. \& McDonald, S.J. 1992. Hydrocarbon contamination on the Antarctic Peninsula. I. Arthur Harbor - subtidal sediments. Marine Pollution Bulletin, 24, 499-506.

KERRY, E. 1990. Microorganisms colonizing plants and soil subjected to different degrees of human activity, including petroleum contamination, in the Vestfold Hills and MacRobertson Land, Antarctica. Polar Biology, 10, 423-430.

KLINGLER, J.M. \& VisHNIAC, H.S. 1988. Water potential of Antarctic soils. Polarforschung, 5, 231-238.

Klute, A. 1986. Water retention: laboratory methods. In Klute, A., ed. Methods of soil analysis, Part 1, Physical and mineralogical methods (2nd ed). Madison, WI: Soil Science Society of America, 635-686.

KRZYSZOWSKA, A. 1990. The content of fuel oil in soil and effect of sewage on water nearby the H. Arctowski Polish Antarctic station (King George Island). Polskie Archiwum Hydrobiologii, 37, 313-326.

MINISTRY FOR THE ENVIRONMENT. 1999. Sampling protocols and analytical methods for determining petroleum products in soil and water. Wellington, NZ: Ministry for the Environment, 56p.

PARKer, C. \& Howard, R.V. 1977. The first environmental impact monitoring and assessment in Antarctica. The Dry Valley drilling project. Biology and Conservation, 12, 163-177.

Rivkina, E.M., Friedmann, E.I., McKay, C.P. \& GilichinSKY, D.A. 2000. Metabolic activity of permafrost bacteria below the freezing point. Applied and Environmental Microbiology, 66, 3230-3233.

SkUJINS, J. 1984. Microbial ecology of desert soils. Advances in Microbial Ecology, 7, 49-89.

Soll SuRvey StafF. 1998. Keys to soil taxonomy. 8th ed. Washington, DC: USDA-NRCC, $326 \mathrm{pp}$.

Tumeo, M.A. \& Wolk, A.E. 1994. Assessment of the presence of oildegrading microbes at McMurdo Station. Antarctic Journal of the United States, 29(5), 375-377. 